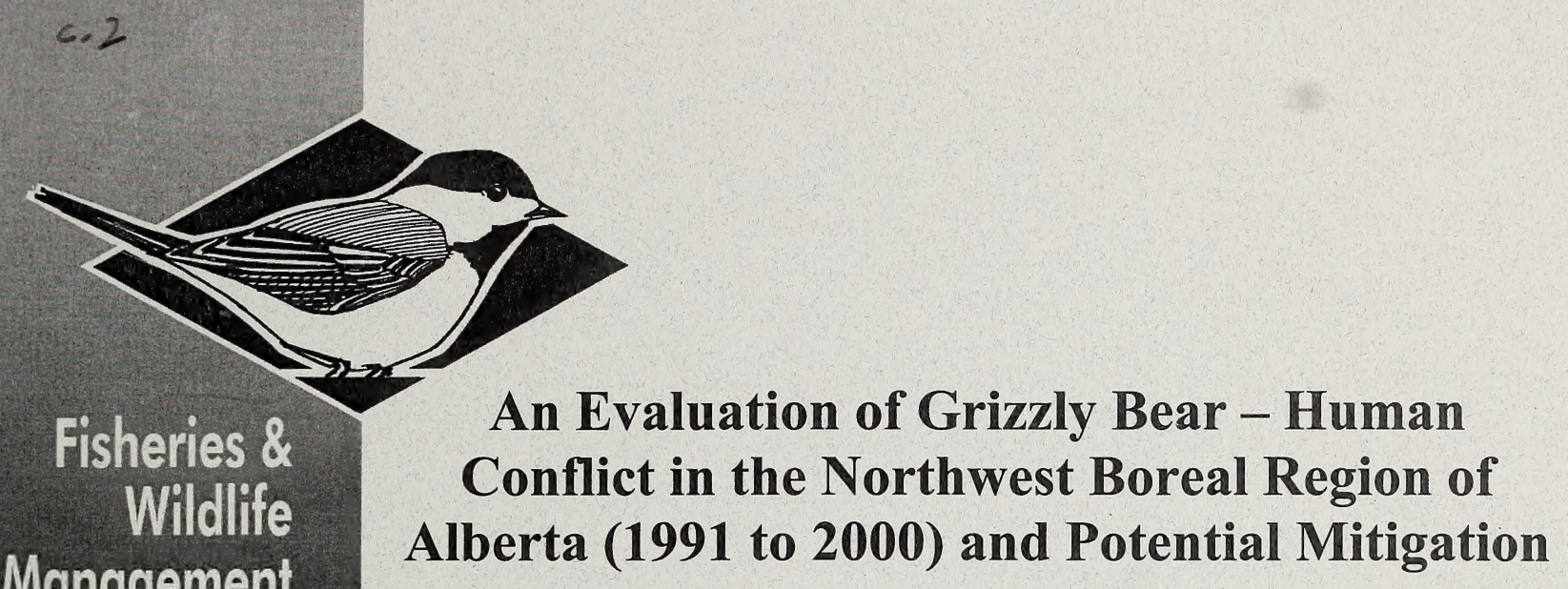

Management Division

RESOURCE STATUS AND ASSESSMENT BRANCH

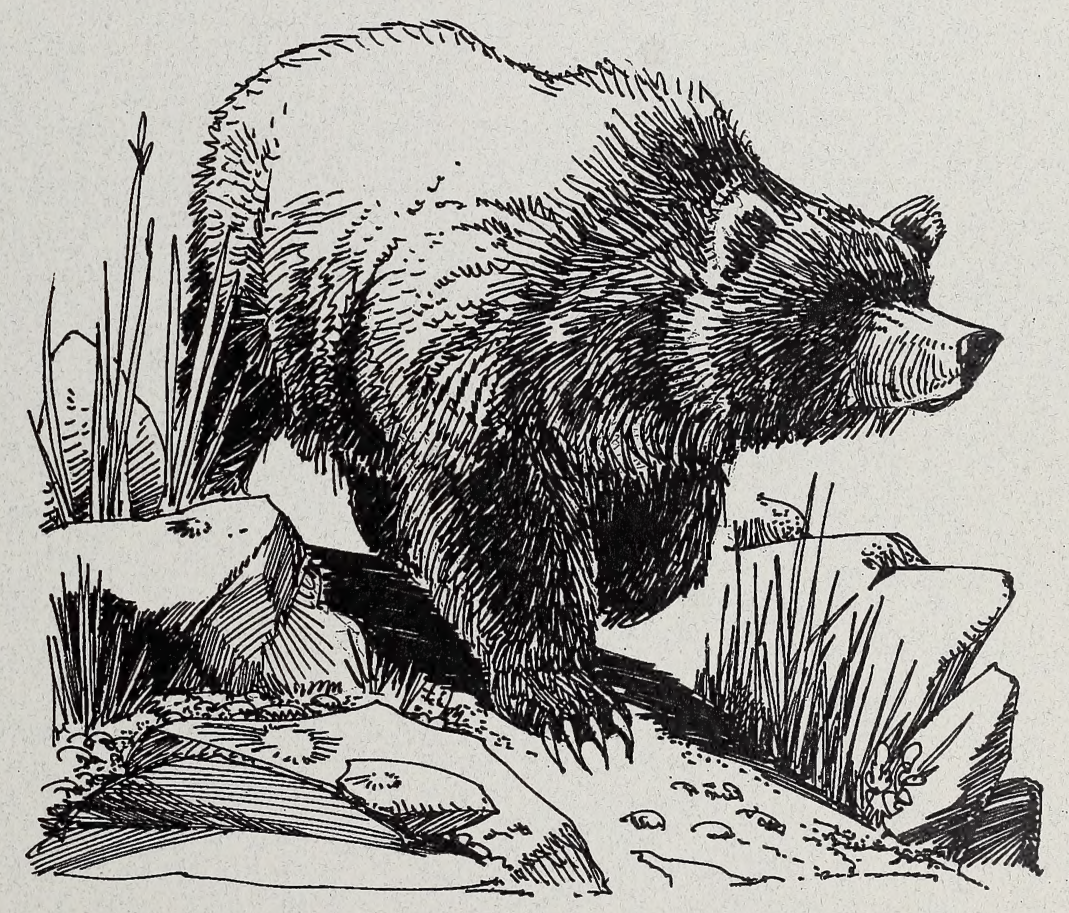

Alberta Species at Risk Report No. 10 



\title{
An Evaluation of Grizzly Bear - Human Conflict in the Northwest Boreal Region of Alberta (1991 to 2000) and Potential Mitigation
}

\author{
Teresa Augustyn
}

Alberta Species at Risk Report No. 10

March 2001

Sustainable ReSOURCE 
Publication No.: I/012

ISBN: 0-7785-1769-1 (Printed Edition)

ISBN: 0-7785-1770-5 (On-line Edition)

ISSN: 1496-7219 (Printed Edition)

ISSN: 1496-7146 (On-line Edition)

For copies of this report, contact:

Information Centre - Publications

Alberta Environment / Alberta Sustainable Resource Development

Main Floor, Great West Life Building

9920108 Street

Edmonton, Alberta

Canada

T5K 2M4

Telephone: (780) 422-2079

OR

Information Service

Alberta Environment / Alberta Sustainable Resource Development \#100, 311512 Street NE

Calgary, Alberta

Canada

T2E 7J2

Telephone: (403) 297-3362

Illustration: Brian Huffman

This publication may be cited as:

Augustyn, T. 2001. An Evaluation of Grizzly Bear - Human Conflict in the Northwest Boreal Region of Alberta (1991 to 2000) and Potential Mitigation. Alberta Sustainable Resource Development, Fish and Wildlife Division, Alberta Species at Risk Report No. 10, Edmonton, $\mathrm{AB}$. 


\section{TABLE OF CONTENTS}

ACKNOWLEDGEMENTS vi

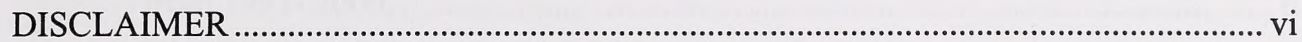

EXECUTIVE SUMMARY ................................................................................. vii

1.0 INTRODUCTION .................................................................................... 1

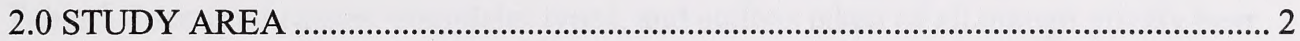

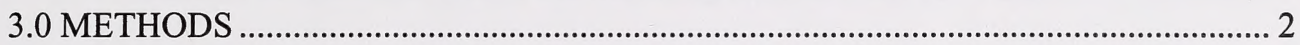

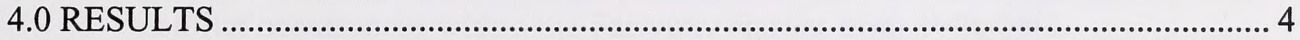

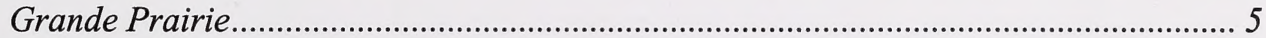

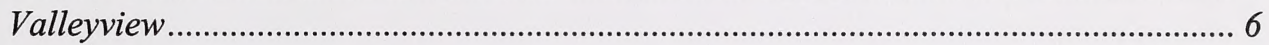

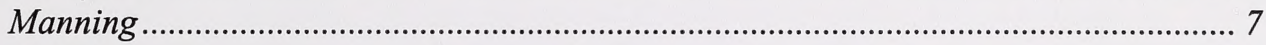

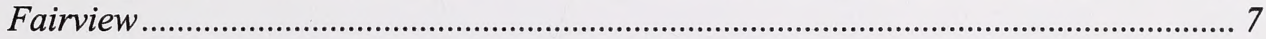

Extent of Education in the Grande Prairie Pilot Area ................................................ 8

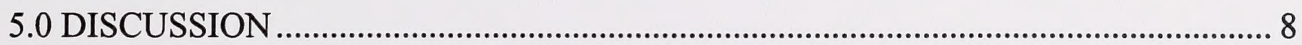

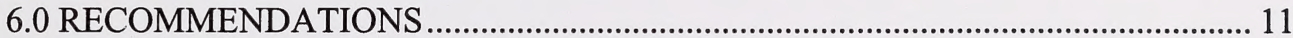

6.1 Bear Awareness Program ............................................................................... 11

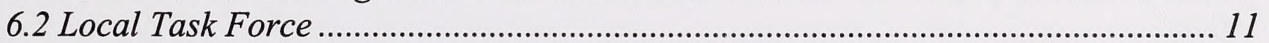

6.3 Carcass Pick-Up Service ............................................................................ 11

6.4 Livestock Management Practices ......................................................................... 12

6.5 Garbage and other Unnatural Attractants ......................................................... 12

6.6 Aversive Conditioning..................................................................................... 13

6.7 Negative aspects of Aversive Conditioning..................................................... 17

6.8 Summary of Recommendations .................................................................. 18

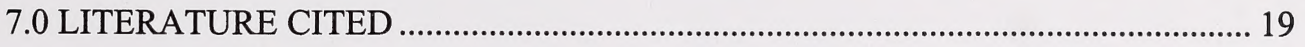

APPENDIX A - Definitions of the complaint types, causes, and actions taken.............. 23

APPENDIX B - Survey questions given to Conservation Officers................................. 25 


\section{LIST OF FIGURES}

Figure 1. The total number of complaints in the Northwest Boreal region of Alberta by

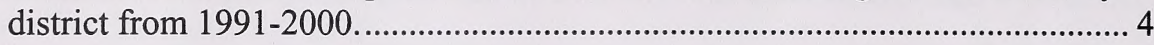

Figure 2. The number of grizzly bear occurrences monthly for the Northwest Boreal region of Alberta by district. 


\section{LIST OF TABLES}

Table 1 Identified causes, complaint types, and actions taken of all grizzly bear occurrences related to human-bear conflict within the Grande Prairie district from 1991- 2000.

Table 2 Identified causes, complaint types, and actions taken of all grizzly bear occurrences related to human-bear conflict within the Valleyview district from 1991- 2000

6

Table 3 Identified causes, complaint types, and actions taken of all human grizzly bear conflict occurrences within the Manning district from 1991-2000.

Table 4 Identified causes, complaint types, and actions taken of all human grizzly bear conflict occurrences within the Fairview district from 1991-2000...................... 


\section{ACKNOWLEDGEMENTS}

District Conservation Officers and biologists from the Northwest Boreal region assisted with the compilation of grizzly bear occurrences. They are:

Dennis Musselman Grande Prairie.

Byron Schram Manning.

Joe Pollock Fairview.

Lewis Watson Valleyview.

Owen Sabiston Fort Vermilion.

Dave Moyles Peace River.

Andy Davison Slave Lake.

Thanks to John Shivik, Blair Hammond, David Hewitt, Kirk Olchoway, Gary Van Spengen, Charles Mamo, Richard Daloise, Rod Silver, Eldon Bruns, and Wayne Norstrom for providing input and experience related to bear-human conflict and bear aware educational programs.

Thanks to Adam James for reviews of several earlier drafts of this report and for the production of maps.

\section{DISCLAIMER}

The views and opinions expressed are those of the author(s) and do not necessarily represent the policies or positions of the Department or the Alberta Government. 


\section{EXECUTIVE SUMMARY}

The grizzly bear (Ursus arctos) is a blue-listed species in Alberta, and in parts of the Northwest Boreal Region it is experiencing an increasing number of conflicts with humans. These conflict situations have brought an increase in the number of public complaints and the number of grizzlies translocated or destroyed. As an initial step in dealing with these problems, this project was initiated to identify the factors that contribute to human-grizzly conflicts and to offer possible solutions.

Using Fish and Wildlife Division occurrence records from the Northwest Boreal Region, information was gathered on grizzly bear sightings and complaints between 1991 and 2000. For each NRS district, the number, type, and cause of grizzly occurrences, and the management practices used to deal with them were summarized. This information has been compiled and analyzed, creating a knowledge base from which future bear management practices can be developed.

Within the region, the total number of complaints has recently increased, with the majority of complaints occurring in the Grande Prairie district. The most common causes of conflict were field grain, livestock predation, domestic carcasses, and garbage. The bears in these situations were often removed or destroyed.

Removing or destroying bears is not an effective, long-term solution because it neither identifies nor eliminates the causes that lead to nuisance bears. Furthermore, it decreases the numbers of a rare species. Many of the grizzly occurrences reviewed had causes that were preventable. Preventative measures to reduce conflicts can be more cost effective than managing problem grizzly bears and they are fundamental to the conservation of the species. While potentially effective practices for dealing with human-bear conflict have been developed in other jurisdictions, many have not yet been fully implemented in the area. Several practices are recommended, including a carcass pick-up service, a bear education program, and several aversive conditioning techniques. These practices, initiated in a timely fashion, consistently maintained, and applied with an understanding of bear behaviour, should reduce conflict. 
Digitized by the Internet Archive in 2016

https://archive.org/details/evaluationofgriz00augu_0 


\subsection{INTRODUCTION}

The grizzly bear is currently listed as Threatened in the United States (U.S. Fish and Wildlife Service 2000) and Vulnerable by the Committee on the Status of Endangered Wildlife in Canada (COSEWIC 2000). The main causes of decline in grizzly bear populations are increased human disturbance, degradation of habitat, high rates of nuisance bear removal, and hunting (COSEWIC 2000). The greatest threat to grizzly bear populations is loss and degradation of wilderness habitat. Loss of habitat occurs mainly through resource extraction and recreational development (Schowalter et al. 2000). Development and recreational activities also result in increased contact with people, posing a further threat to this species (Schowalter et al. 2000). The expansion of human development and habitat loss has drastically reduced the grizzly bears' range. The historical range of the grizzly bear once extended from Alaska to the western Northwest Territories, across the western half of North America to Manitoba in the east, and to California and Mexico in the south (COSEWIC 2000). Today, the grizzly bear is found only in Alaska, the Yukon, Northwest Territories, Nunavut, British Columbia, western Alberta, and northwestern United States (Schowalter et al. 2000). In 1990 COSEWIC estimated that $63 \%$ of the Canadian grizzly bear population was designated at risk, either vulnerable or threatened (MELP 1995). At present, the grizzly bear is a blue-listed species in British Columbia (Ciarniello 1997) and Alberta (Alberta Environment 1997).

The primary range of grizzly bears in Alberta includes montane, subalpine, and alpine habitat regions in and adjacent to the Rocky Mountains, and boreal mixed-wood, boreal foothills and boreal upland habitat regions in west-central Alberta (Alberta Forestry, Lands and Wildlife 1990). The largest area of grizzly bear habitat occurs in west and west-central Alberta, extending from the British Columbia border east to include the area from Jasper National Park-Willmore Wilderness north and northeast to Grande Prairie, Swan Hills and Edson (Alberta Forestry, Lands and Wildlife 1990). Grizzly bear distribution is discontinuous in the boreal mixed-wood and boreal upland habitats in the Peace River-Grande Prairie area and in the aspen parkland in southern and central regions of the province. Little is known of their distribution in the boreal subarctic regions of northwestern Alberta (Alberta Forestry, Lands and Wildlife 1990).

In the Northwest Boreal Region of Alberta, growth of human settlement, agriculture, industry and recreation on private and public lands have led to the loss, alienation, and fragmentation of bear habitat. This loss of habitat forces bears to live in close proximity with humans, creating conflicts between the two species. With this conflict comes the demand for bear removal or destruction. Human-bear conflict is one of the leading causes of grizzly bear mortality, and it is essential that the sources of conflict be identified, analyzed and resolved. This study was conducted in the Northwest Boreal Region to explore the relationship between humans and grizzly bears. The study was designed to provide information on human-bear conflicts in the region and provide suggestions to mitigate conflicts in a pilot area west of Grande Prairie. This report summarizes the number, type, and cause of grizzly occurrences, and the management practices used to deal with them since 1991, and recommends additional management techniques that may help to reduce future conflicts. 


\subsection{STUDY AREA}

The Northwest Boreal Region is one of six Alberta Sustainable Resource Development regions in the province. It covers approximately $229215 \mathrm{~km}^{2}$ of land $(34 \%$ of the province) and includes approximately $5.5 \%$ of the human population (Alberta Environment 2000). The region includes 11 NRS districts: Peace River, Fairview, Valleyview, Grande Prairie, Fort Vermilion, Slave Lake, High Level, Red Earth, Spirit River, High Prairie, and Manning.

Regionally there is a wide array of natural resources including agricultural land, hardwood and softwood timber, energy resources, grazing land, water, wildlife, fish, recreational features, historical and archaeological resources and gravel (Alberta Environment 2000). While agriculture is the established base in southern parts of the region, extensive development of timber resources, oil and gas have expanded in the Peace area (Alberta Environment 2000). Moderate but steady growth is expected from continued development of these resources (Alberta Environment 2000).

The Northwest Boreal region of Alberta provides approximately $26 \%$ of the current primary ranges available to grizzly bears (approximately $31263 \mathrm{~km}^{2}$ ). This range supports about $16 \%$ of the estimated provincial resident population (Alberta Forestry, Lands and Wildlife 1990). Grizzly bears use habitat primarily in the boreal mixed-wood, boreal upland, and aspen parkland in the region on both private and public land.

\subsection{METHODS}

Grizzly bear complaints and sightings reported by the public to Alberta Sustainable Resource Development, Fish and Wildlife Division are documented in the permanent occurrence records of each district. Each occurrence report contains the type, species name, complainant, date, legal land description, short description of the occurrence, action taken, staff time, number of animals, and reporting Officer.

To obtain information on human-bear conflicts in the Northwest Boreal region, I evaluated grizzly bear occurrences since 1991 from 5 districts (G.P., Fv. Man. P.R., V.V.). Data was collected from each grizzly occurrence by accessing the occurrence logbooks in each district. The collected data was then categorized into 18 sections:

- occurrence file number

- date

- complaint type

- complainant

- reported number of adults

- reported number of cubs
- confirmed number of adults - confirmed number of cubs

- age of adults

- age of cubs

- general information

- sex of adults
- general location

- legal land description

- identified cause

- action taken

- district

- staff time

From this point, sections were examined for the information they provided pertaining to human-bear conflict. Each occurrence was mapped to identify the core problem areas of 
grizzly bear occurrences in the region. The short descriptions of the occurrence and the action taken was analyzed to determine the causes of conflict, the management actions taken, and the number of bears relocated or destroyed. The complaint type was analyzed to identify the concerns of the public. Staff time was also logged for each occurrence so that the total time spent on grizzly bear occurrences was noted for each district and for the region.

Information on complaints, causes, and actions was subdivided and tabulated under the following headings (see Appendix A for definitions):

Complaint Type

livestock predation

public safety

field crop damage

relocation required

wildlife carcass

wildlife predation

aggressive encounter

bear destroyed

bee predation

property damage

Cause
livestock predation
field grain
domestic carcass
wildlife carcass
vegetation
garbage
wildlife predation
bee predation
starvation/injury
curiosity
cub protection
illegal hunting
legal hunting
unknown

Action

montiored cause removed snare set/no capture bear removed bear destroyed refer to other district

Not all grizzly occurrences were problematic. Sighting reports did not involve conflicts, but were observations of bears by the public given to Fish and Wildlife staff for informational purposes. The $51 \%$ of grizzly bear occurrences related to human-bear conflict on either private or public land was the focus of this study.

A survey was also conducted to determine the extent of bear education in the Grande Prairie pilot area. In order to gain an understanding of the extent and level of education presented to the public, the Conservation Officers from the Grande Prairie district were surveyed. The survey questions are summarized in Appendix B.

While all grizzly bear occurrences with land locations were mapped, those occurrences without land locations (a total of 24) were not mapped, but are still included in this report. Mapping of grizzly bear occurrences was completed for both the region and the Grande Prairie Pilot area. Maps are on file at the Peace River Fish and Wildlife office.

Not all grizzly bear occurrences were confirmed by Fish and Wildlife staff. An occurrence was considered confirmed when a Conservation Officer had patrolled the area and verified that a grizzly bear was in the area or the complainant was considered a reliable source. Confirmed and unconfirmed occurrences were both documented in this report. 
Details of individual grizzly bear occurrence records from 1991-2000 compiled in this report were stored in the Biodiversity/Species Observation Database maintained by Alberta Sustainable Resource Development.

\subsection{RESULTS}

A total of 375 grizzly bear occurrences from the last ten years were reviewed. Of the 375 occurrences, 184 (49\%) were sightings. For the majority of sightings, $(93 \%)$ the cause of the bear's presence was unknown. The other $191(51 \%)$ occurrences were related to human-bear conflict on either private or public land. For these occurrences, $20 \%$ of the causes were unknown. The number of occurrences each year and each month are summarized for each district in Figures 1 and 2 respectively.

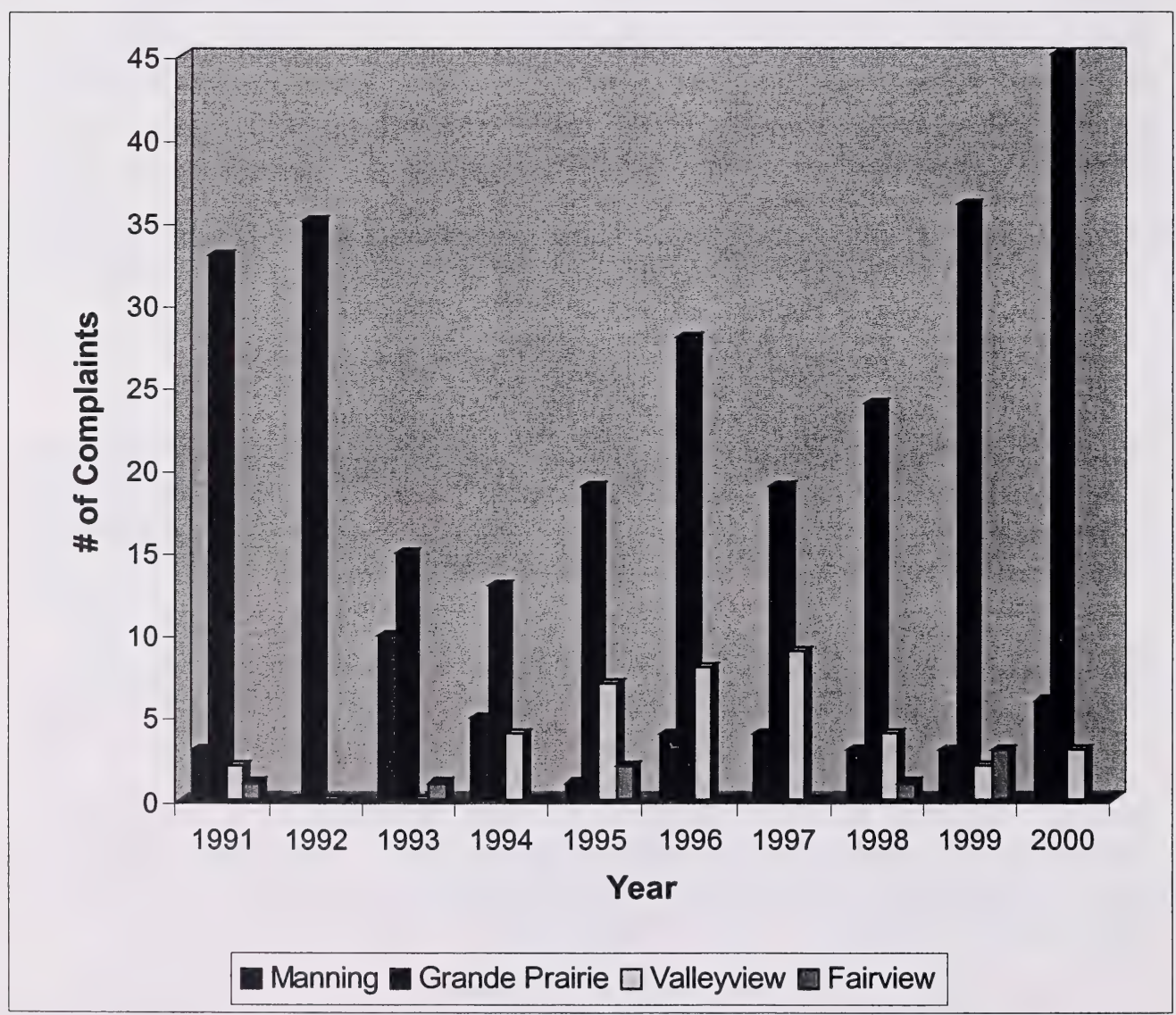

Figure 1. The total number of complaints in the Northwest Boreal region of Alberta by district from 1991-2000. 


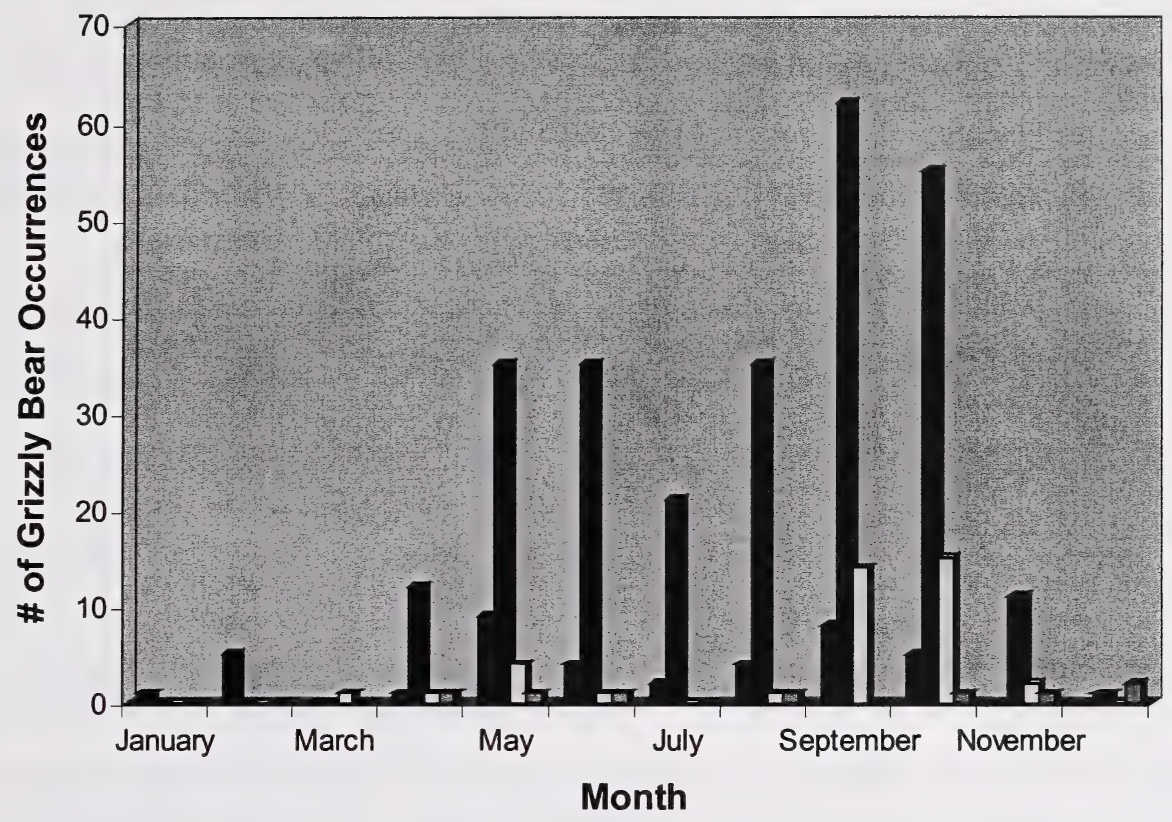

Manning Grande Prairie $\square$ Valleyview Gairview

Figure 2. The number of grizzly bear occurrences monthly for the Northwest Boreal region of Alberta by district.

\subsection{Grande Prairie}

Within the Grande Prairie district the total number of grizzly bear occurrences from 1991-2000 was 267. Most of the grizzly bear occurrences over the last ten years were related to human-bear conflict on private lands $(56 \%)$, the other $44 \%$ were reported sightings. The conflicts are summarized in Table 1 . A total of 20 grizzly bears were destroyed because of human-bear conflicts on private lands, two destroyed by Conservation Officers for control action and 18 destroyed by complainants. Conservation Officers translocated 14 grizzly bears from the area. 
Table 1: Identified causes, complaint types, and actions taken for grizzly bear occurrences related to human-bear conflict within the Grande Prairie district from 19912000.

\begin{tabular}{|c|c|c|c|c|c|c|c|c|}
\hline Complaint Type & Total No. & $\%$ & Identified Cause & Total No. & $\%$ & Action Taken & Total No. & $\%$ \\
\hline Livestock Predation & 59 & 40 & Field Grain & 32 & 21 & Monitored & 72 & 48 \\
\hline Public Safety & 24 & 16 & Livestock Predation & 28 & 19 & Cause Removed & 22 & 15 \\
\hline Field Crop Damage & 20 & 13 & Unknown & 27 & 18 & Bear Destroyed & 20 & 13 \\
\hline Bear Destroyed & 15 & 10 & Domestic Carcass & 23 & 16 & Snare Set/No Capture & 18 & 12 \\
\hline Aggressive Encounter & 14 & 9 & Garbage & 10 & 7 & Bear Removed & 14 & 9 \\
\hline Wildlife Predation & 10 & 8 & Wildlife Predation & 10 & 7 & Refer to Other District & 3 & 3 \\
\hline Wildlife Carcass & 2 & 1 & Wildlife Carcass & 6 & 4 & & & \\
\hline Relocation Required & 2 & 1 & Illegal Hunting & 4 & 3 & & & \\
\hline Bee Predation & 2 & 1 & Vegetation & 2 & 1 & & & \\
\hline \multirow[t]{4}{*}{ Property Damage } & 1 & 1 & Bee Predation & 2 & 1 & & & \\
\hline & & & Cub Protection & 2 & 1 & & & \\
\hline & & & Starvation/Injury & 2 & 1 & & & \\
\hline & & & Curiosity & 1 & 1 & & & \\
\hline Total & 149 & 100 & Total & 149 & 100 & Total & 149 & 100 \\
\hline
\end{tabular}

The total staff time spent on grizzly bear occurrences in the last ten years was 3,555.8 hours. Mapping of all grizzly bear occurrences identified the core problem areas, which included Elmworth (35), Goodfare (31), Beaverlodge (24), Grovedale (21), Hythe (14), Wembley (12), and the Kakwa area (11). A total of 34 occurrences were unconfirmed in the Grande Prairie area.

\subsection{Valleyview}

Within the Valleyview district, the total number of grizzly bear occurrences from 19912000 was 39 . Most grizzly bear occurrences over the last ten years were related to human-bear conflict (62\%) on private and public lands. The conflicts are summarized in Table 2. A total of six grizzly bears were destroyed as a result of human-bear conflicts on private lands, with complainants destroying all six bears. Conservation Officers translocated a sow and a cub from the area.

Table 2 Identified causes, complaint types, and actions taken of all grizzly bear occurrences related to human-bear conflict within the Valleyview district from 19912000.

\begin{tabular}{|c|c|c|c|c|c|c|c|c|}
\hline Complaint Type & Total No. & $\%$ & Identified Cause & Total No. & $\%$ & Action Taken & Total No. & $\%$ \\
\hline Livestock Predation & 6 & 25 & Unknown & 7 & 29 & Monitored & 9 & 38 \\
\hline Bear Destroyed & 6 & 25 & Wildlife Carcass & 7 & 29 & Cause Removed & 8 & 33 \\
\hline Public Safety & 5 & 21 & Livestock Predation & 3 & 14 & Bear Destroyed & 6 & 25 \\
\hline Wildlife Carcass & 4 & 17 & Garbage & 2 & 8 & Bear Removed & 1 & 4 \\
\hline Wildlife Predation & 2 & 8 & Wildlife Predation & 2 & 8 & & & \\
\hline \multirow[t]{3}{*}{ Property Damage } & 1 & 4 & Domestic Carcass & 1 & 4 & & & \\
\hline & & & Cub Protection & 1 & 4 & & & \\
\hline & & & Illegal Hunting & 1 & 4 & & & \\
\hline Total & 24 & 100 & Total & 24 & 100 & Total & 24 & 100 \\
\hline
\end{tabular}


The total staff time spent on grizzly bear occurrences in the last ten years was 179 hours. Mapping of all grizzly bear occurrences identified the problem areas, which consisted of Simonette River (8), Suncor Plant/Canfor Camp (7), and Sunset House (4).

\subsection{Manning}

In the Manning district, most of the 41 grizzly bear occurrences over the last ten years were reported sightings ( $80 \%)$. The other $20 \%$ were related to human-bear conflict on public land. The conflicts are summarized in Table 3. A total of five grizzly bears were destroyed because of human-bear conflicts on public land, with complainants destroying all five bears. Conservation Officers translocated no grizzly bears from the area.

Table 3 Identified causes, complaint types, and actions taken of all human grizzly bear conflict occurrences within the Manning district from 1991-2000.

\begin{tabular}{|lll|lll|lll|}
\hline Complaint Types & Total No. \% & ldentified Causes & Total No. & $\%$ & Action Taken & Total No. & $\%$ \\
\hline Bear Destroyed & 5 & 64 & Wildlife Carcass & 2 & 25 & Bear Destroyed & 5 & 63 \\
Property Damage & 1 & 12 & Legal Hunting & 3 & 38 & Cause Removed 2 & 25 \\
Aggressive Encounter & 1 & 12 & Unknown & 2 & 25 & Monitored & 1 & 12 \\
Wildlife Carcass & 1 & 12 & Illegal Hunting & 1 & 12 & & & \\
Total & 8 & 100 & Total & 8 & 100 & Total & 8 & 100 \\
\hline
\end{tabular}

The total staff time spent on grizzly bear occurrences in the last ten years was 67 hours. Mapping of all grizzly bear occurrences identified the problem areas, which included Cranberry Plant (6), Keg River (4), and Manning (4). A total of two occurrences were unconfirmed in the Manning area.

\subsection{Fairview}

All 8 grizzly bear occurrences in the Fairview district were related to human-bear conflict. The conflicts are summarized in Table 4 . A total of three grizzly bears were destroyed due to human-bear conflicts on private land and illegal hunting, with the complainants destroying all three bears. Conservation Officers translocated no grizzly bears from the area.

Table 4 Identified causes, complaint types, and actions taken of all human grizzly bear conflict occurrences within the Fairview district from 1991-2000.

\begin{tabular}{|lll|lll|lll|}
\hline Complaint Type & Total No. & $\%$ & Identified Cause & Total No. & $\%$ & Action Taken & Total No. & $\%$ \\
\hline Bear Destroyed & 3 & 38 & Unknown & 4 & 50 & Monitored & 4 & 50 \\
Public Safety & 2 & 25 & Illegal Hunting & 2 & 25 & Bear Destroyed & 3 & 38 \\
Field Crop Damage & 1 & 13 & Field Grain & 1 & 13 & Snare Set/No Capture & 1 & 12 \\
Livestock Predation & 1 & 13 & Livestock Predation & 1 & 12 & & & \\
Relocation Required & 1 & 11 & & & & & & \\
Total & 8 & 100 & Total & 8 & 100 & Total & 8 & 100 \\
\hline
\end{tabular}

The total staff time spent on grizzly bear occurrences in the last ten years was 19.75 hours. Mapping of all grizzly bear occurrences identified the problem area, which was Fairview (4). One occurrence was unconfirmed in the Fairview area. 


\subsection{Extent of Education in the Grande Prairie Pilot Area}

Data obtained by surveying the Conservation Officers was used to determine the extent of bear education for the public in the Grande Prairie Pilot area. Within this area, the high number of human-bear conflicts has necessitated an increasing amount of time and attention spent on the problem. One action prompted by the recent increase in conflict was the increase of bear education for the public. Every grizzly bear occurrence documented over the last ten years has required time and effort from Conservation Officers to educate the public. Staff members have spoken with approximately 263 complainants about bear safety. Discussing bear issues with local residents, Conservation Officers spent roughly 50 hours annually educating people about bears and their behaviour (Musselmann pers. comm.). During these discussions, Conservation Officers explained the risks involved with the presence of bears, when actions are taken to relocate a bear, ways to avoid attracting bears, how to discourage their presence, and ways to co-exist with bears (Musselman pers. comm.). The groups of people who received education included ranchers, farmers, rural residents, industrial workers, urban residents, recreational land users, and hunters.

Education was relatively similar for all audiences, but was adapted and changed to meet the needs of the audience. Education was directed to the level of knowledge of the audience, what situations might bring them in contact with bears, appropriate actions when encountering a bear, and ways to identify the types of bear behaviour (aggressive versus curiosity). Parts of the education involved influencing the audiences' outlook towards a greater understanding and appreciation of bears. The Conservation Officers have presented information on an annual basis to grades 5 to 8 school classes, outdoor groups, church camps, scouts/girl guides, and for industrial safety meetings (Musselman pers. comm.). While the requests for education have already grown, an even greater need is anticipated for the future.

\subsection{DISCUSSION}

While human-bear conflicts are problematic in all the areas surveyed, only two areas have shown an increase recently, the Grande Prairie and Manning districts. Of these two, the Grande Prairie area has shown a much higher number of conflicts. Despite fluctuations, the last four years have shown a steady increase leading to a higher number of complaints than recorded in any previous year over the last ten years (Figure 1). In the future, even more complaints are to be expected unless effective intervention is implemented. With these rising numbers of conflict in recent years, a precarious situation is developing which requires prompt attention. In Manning, a steady increase of complaints has also been recorded in the last few years.

Unlike the Grande Prairie and Manning districts, which have demonstrated a steady increase in the number of complaints in recent years, the other districts have shown a decline. For the Valleyview district, there was no significant rise in the number of complaints over the last ten years (Figure 1). Following 1997, there was a decline in the number of complaints. For the Fairview district, the number of complaints was sporadic throughout the years with no significant rise in the number of complaints (Figure 1). 
The majority of complaints in the Grande Prairie and Fairview districts were conflicts between bears and landowners on private lands. These private lands are in grizzly bear habitat and produce unnatural food sources, such as livestock, oat fields, and domestic carcasses that attract the bears. The complaints from the Valleyview and Manning districts were mostly from land users, such as industrial workers, hunters, and recreational users while on public land. The land users in grizzly bear country create both unnatural (garbage) and natural (wildlife carcasses) food sources that attract bears into human used areas.

The number of monthly grizzly bear occurrences appeared to be consistent in all districts (Figure 2). For all districts, the highest numbers of grizzly bear occurrences were in the months of September and October with the second highest in May and June. Consequently, specific management practices can be concentrated during these time frames.

Conflicts between humans and bears resulted from several causes (Tables 1-4). Most conflicts involved either field grain, livestock predation, domestic carcasses, garbage, or wildlife carcasses,. Field grain, particularly oats, was responsible for $17 \%$ of the conflicts on private lands in the region. Readily available oats attracted bears onto fields to feed, leaving landowners and the general public concerned for public safety and field crop damage. Livestock predation (17\%) was another leading cause of conflict on private lands in the region. In spite of the compensation program, landowners were concerned with the loss of livestock as compensation is based on evidence, which is difficult and sometimes impossible to obtain. In $13 \%$ of cases, conflict resulted from domestic carcasses. Bears were attracted to private lands because domestic carcasses were not properly removed or disposed of. Garbage and other unnatural attractants represented $6 \%$ of the causes. When these unnatural attractants, such as animal feed, gardens, composts, and garbage, were not removed or properly stored, bears were repeatedly attracted to private lands.

On public land, the primary cause of conflict was identified as wildlife carcasses, representing $8 \%$ of the total causes in the region. Wildlife carcasses, resulting from roadkills, hunters, and predators, left in areas of human activity and development attracted bears.

Predictably, the types of complaints were related to the causes of bear human conflict (Tables 1-4). These complaints demonstrated the primary concerns of citizens who lived and played in grizzly bear country. For the region, the main complaints included livestock predation, public safety, field crop damage, aggressive encounters, and bears destroyed. Livestock predation represented $35 \%$ of the complaints. Landowners depended on Fish and Wildlife staff to provide ways to reduce and prevent livestock predation on private lands, emphasizing the need to find alternative strategies to reduce livestock predation. Another leading complaint was for public safety, representing $17 \%$ of complaints. The public contacted Fish and Wildlife staff to learn how to handle bear encounters and what bear safety practices they should be adopting, stressing the need for a more extensive bear education program. Field crop damage represented $11 \%$ of the 
complaints. The bears feeding in the oat fields led to the destruction of crops, highlighting the need to discourage bears from consuming oats as a food source. An additional complaint was aggressive encounters, constituting $8 \%$ of the complaints. The majority of people, who encountered an aggressive bear, were unsure how to handle the situation properly. Usually destruction of the bear resulted, calling attention again to the importance of having more time and effort spent on a bear aware education program. Another reoccurring complaint was the destruction of a bear (15\%). Complaints regarding the destruction of a bear usually involved a person who killed a bear in selfdefense, or in legal or illegal hunting. The majority of bears were killed because of surprise encounters that resulted in the person shooting the bear in self-defense. These surprise encounters can be reduced by educating people to become familiar with bear signs, ways to avoid bears, and appropriate actions to use when encountering a bear.

In roughly half of the grizzly bear occurrences, the action taken was to monitor the bear $(45 \%)$. Fish and Wildlife staff's first step, if the bear was a one-time offender, was to leave the bear alone and request the public to monitor the bear. If the bear continued to be a problem and became a second or third time offender, the next action used was to remove or destroy the bear. The number of bears destroyed (18\%) was higher than the number of bears removed ( $8 \%$ ) because of the low probability of capturing the bear. While a large percentage of actions taken involved setting up snare sets (10\%), most bears were not caught. Another action taken was removing the cause that was attracting the bear $(17 \%)$, usually a livestock or wildlife carcass. The Conservation Officers removed these causes regularly, demonstrating the need for an efficient and effective way to remove carcasses. Currently $26 \%$ of direct intervention for human-bear conflict is moving or destroying the bear. While the removal or killing of the bear is a short-term solution, it only temporarily reduces the conflict. If the cause is not removed, the same or other bears will return to the site. Conservation Officers in the Northwest Boreal region have put in a total of 3955.6 hours of time and effort on human grizzly bear conflict. This huge amount of time makes it apparent that the need to reduce conflict is of importance.

In summation, grizzly bear occurrences and human-bear conflicts are on the rise and are likely to continue without intervention. This rise in conflict is because of the expansion of human populations and activities into bear habitat. The growth of human settlement, agriculture, industry and recreation increasingly brings people and bears in close proximity. Understanding and respecting human and grizzly bear needs is a first step in bringing about effective solutions to the resulting problems. While the critical situation developing in some areas has received attention, escalating needs of the situation have not yet prompted corresponding increases in resources. Poised between issues of public safety on the one hand and concerns for the bear population on the other, Conservation Officers are left in an untenable situation without the time or resources to deal effectively with the increases in grizzly bear occurrences. While newly developed management techniques make modern solutions appear tantalizingly near, they have not yet been placed within reach. Immediate intervention is required to meet the demands of this situation. 


\subsection{RECOMMENDATIONS}

Concentrations of grizzly bears on private lands have resulted from a number of causes, including domestic carcasses, oat crops, livestock predation, wildlife carcasses, and garbage attractants. It is readily apparent that reducing the identified causes will bring about a corresponding decrease in human-bear conflicts. As with most wildlife problems, no single method exists that will provide a way to reduce all human-bear conflicts. However, certain techniques initiated in a timely fashion, consistently maintained, and applied with an understanding of bear behaviour, will reduce the likelihood of conflict.

\subsection{Bear Awareness Program}

Human-bear conflict has resulted in many grizzly bears being killed or removed, often because of a lack of understanding of bears. In many cases, the situation could have been prevented. To reduce these preventable conflicts, a more comprehensive bear awareness program should be developed and implemented. While the primary goal of a bear aware program is to give people the knowledge to reduce unnatural food attractants and information for coexisting with bears, there should be two distinct courses in the program that target different groups. The first group, referred to as 'land users', is comprised of recreational users, urban residents, industrial or research backcountry users, and hunters. Most of the bear-human conflicts with this particular group are caused by garbage, unnatural food attractants, wildlife carcasses, and not adhering to bear safety tips. One component of the bear awareness program should address these conflict issues for the land user group. The second group is made up of ranchers, farmers, and rural residents who are referred to as "landowners". Most of the bear-human conflicts with landowners result from domestic carcasses, livestock predation, and oat crops. The second component of the bear awareness program should address these conflict issues for landowners. The main purpose of the bear awareness program is to create a community that has a minimal impact on the health and population dynamics of bears and to drastically reduce bear-human conflicts.

\subsection{Local Task Force}

Establishing a local task force would be another useful strategy. The local task force, comprised of farmers, ranchers, Fish and Wildlife staff, and other interest groups, would be involved in alleviating human-bear conflict and fostering conservation efforts. The main objective of the committee would be to understand interactions between bears and landowners and develop ways to help landowners and bears co-exist.

\subsection{Carcass Pick-Up Service}

Dealing with the improper disposal of carcasses, both domestic and wild, with a carcass pick-up service would reduce conflict. This service needs to operate in the core problem areas. Co-operation among provincial and municipal governments, and the local task force would be necessary to establish an effective service. The service would also dispose of carcasses in an appropriate site. 


\subsection{Livestock Management Practices}

Good livestock management practices help prevent bears obtaining easy access to unnatural foods and becoming problem bears. The following are suggestions to help prevent problem bears:

Livestock predation can be reduced by the prompt disposal of livestock carcasses. In order to ensure the immediate removal of carcasses, landowners need to patrol their pastures routinely to keep tabs on dead livestock and to dispose of the carcasses immediately in a boneyard. It is recommended that the bone yard be surrounded by an electric fence and covered regularly with soil and chemicals to eliminate odour.

Livestock predation can also be reduced by the protection of calves. During the calving season, confine pregnant animals near occupied buildings. This will protect calves and prevent grizzly bears from accessing carcasses of newborns that die from natural causes. It is not advised to calve in forested or bushy pastures. The controlling of birth seasons rather than allowing births to take place randomly will further protect calves from predation (Cat Specialist Group 1996).

Livestock will be more protected if they are moved to a more secure area at night (O'Brien 1997). If possible, confine livestock in a fenced area close to a residence or farm building, which has lights, during the night. Although this maybe a practical solution for small herds, it is not feasible for large herds.

Landowners, keeping records of how many animals are in particular pastures, will quickly determine when losses begin (O'Brien 1997). The record keeping also acts as a logbook that can be used to identify loss patterns and high risk pastures. Keeping track of losses can be very beneficial in control or removal of the problem predator.

Livestock behaviour is useful as indirect evidence of predation. The presence of threatening carnivores will cause most cows to bawl and attempt to locate their young (Wade and Bowns 2000). Their behaviour will be alert, much exaggerated from normal and will include urgent calling, running to find their calves and attempts to chase the carnivores (Wade and Bowns 2000). Behaviour of livestock in herds, which are raided repeatedly by predators, becomes more alert and defensive. To the person versed in livestock production and familiar with the individual herd, abnormal behaviour is readily apparent and indicates a reaction to an unusual disturbance. This can act as a warning system for landowners.

Keeping, rather than selling or trading, experienced herd lead animals, so that they can teach appropriately cautious behaviour to younger animals is recommended, as is keeping a few cows or steers with horns in the calving herd (Cat Specialist Group 1996).

\subsection{Garbage and other Unnatural Attractants}

Unnatural attractants include garbage, pet food, composts, gardens, bird feed, and numerous other items. Informing land users and landowners that the availability of these attractants is largely responsible for problems with bears is fundamental. Equally 
important is providing citizens with alternative strategies and resources that will reduce the availability of attractants to bears.

There are a number of ways to make garbage unavailable for bears. In the wilderness, garbage should be deposited in available wildlife-resistant trash containers in camping areas and high human activity areas (Hammond pers. comm.). Camps and human activity use areas should be kept clean at all times. All landfills and dumps should be surrounded with electric fencing. Garbage in rural residential areas should be placed in bear proof containers that have tight-fitted lids and stored in a secure building (Hammond pers. comm).

Most other attractants can be dealt with quite simply. Dog food and other animal foods should not be stored where bears can access them (Van Spengen pers. comm.). Birdseed should only be used when the birds need it during the winter and with the feeder installed so that it is inaccessible to bears. Oil, grease, dairy products, meat, and bones should not be put into composts. To control odour, adding small amounts of lime is effective. (Van Spengen pers. comm.). As residue on barbecues can build-up and attract bears, grills should be cleaned immediately and stored in a secure location. Beehives can be raised on a platform or circled with an electric fence and fruits and vegetables should be harvested as soon as they are ripe (Van Spengen pers. comm.).

\subsection{Aversive Conditioning}

Aversive conditioning is modifying previously established undesirable behaviour through the use of deterrents (Hunt 1984). Deterrents include plastic slugs, rubber bullets, electric shock, emetic or foul-tasting chemicals, acoustic devices, and trained bear dogs (Ciarniello 1997). Aversive conditioning is becoming increasingly recognized as an effective and acceptable tool for altering the behaviour of bears. During aversive conditioning, a negative reinforcer (aversive agent) is presented while the bear is engaging in undesirable behaviour (Gillian et al. 1994). This teaches the bear to associate the unconditioned stimuli (negative experience) with the conditioned stimuli (undesirable behaviour) (Ciarniello 1997). Repeated application of the aversive agent teaches the bear to avoid the site or attractant and cease the behaviour in the future. Ultimately, the goals are to alter the behaviour of the bear, to instil a fear of humans, and to avoid the removal or destruction of the bear (Ciarniello 1997). Most successful programs use an integrated approach, combining removal or reduction of the cause of conflict with effective aversive conditioning control measures.

Electric fences are an effective barrier to unnatural food sources for bears. However, electric fences do require routine inspections and maintenance to ensure proper operation and protection capability. Electric fences are known to result in a high percentage of bears that are scared away forever. In the United States and Canada, electric fencing has been successfully used to prevent bear predation on livestock and beehives (Shivik and Mamo pers. comm.).

Scare devices are used to disrupt predatory behaviour, to discourage animals from becoming habituated to unnatural food sources, and to prevent animals from approaching 
humans, developments, garbage dumps, and campgrounds. Scare devices include plastic slugs, rubber bullets, explode cannons, and flashing lights. In Wyoming this spring, scare devices are being studied and will be used on grizzly bears to determine the most effective tools for this species (Shivik pers. comm.). Scare devices are often used in combination with an acoustic deterrent. Acoustic devices produce sharp, loud sounds, biologically significant sounds, or combinations of sound with other stimuli (Hunt 1984). Acoustic devices include sirens, fireworks, gunfire, music, and bells. Some examples include the combination of strobe lights and sirens, called electronic guards, with a motion sensor. Electronic guards with motion sensors are effective because they produce a multiple stimulus that is only triggered by a bear's presence (Shivik pers. comm.). Another device is the propane operated scare gun called the ZON scare gun. Several ZON scare guns are placed around oat fields or livestock pastures. The scare guns work on timers that randomly fire and are positioned on tripods to allow the scare guns to move 360 degrees, making it sound like the noise is coming from all directions. However, the scare gun would be more effective if the gun could be triggered by the presence of a bear instead of firing randomly, regardless of a bear's presence. The scare gun has the potential to be very effective if hooked up to motion sensors that would trigger the firing when a bear is in the area and if a negative experience occurred afterwards. This would also reduce the amount of noise disturbance for nearby neighbours. A form of an acoustic deterrent is the "Critter Gitter". The Critter Gitter has been tested in Colorado as a behaviour contingent device for keeping predators away from a resource (Shivik pers. comm.). The Critter Gitter is a motion detector that is hooked up to a buzzer. The Critter Gitter can be put on fences, carcasses, garbage cans, porches or decks, and will buzz if the motion sensor picks up a movement. In Colorado, it has been tested with captive coyotes with varying levels of success (Shivik pers. comm.). The Critter Gitter has also been researched with bears in Montana and has proven to be effective for a short time period. The Critter Gitter would be more effective if there was a negative experience after the noise. Bears can learn to ignore the noise if there is no negative experience and if they receive a food reward for disregarding the noise, rendering the device ineffective.

A study in the Yellowstone National Park evaluated the effectiveness of an aversive agent (scare device) with conditioning auditory stimuli (acoustical deterrent) on five nuisance female grizzly bears, two accompanied by their young (Gillin et al. 1994). Several aversive agent delivery systems were used. The Thumper gun and flare guns were used with either rubber bullets, bear deterrent cartridge, or Ferret Soft Slugs. During the aversive conditioning, taped calls of California quail and the ladder-backed woodpecker were also used to provide an acoustic deterrent. The results indicated that the application of the aversive techniques altered their nuisance behaviour temporarily. The results also demonstrated the difficulty of conditioning female grizzly bears, which may be related to their small and sometimes restricted home ranges (Gillin et al. 1994).

A study conducted in Denali National Park administered aversive conditioning from 1982 to 1994 on both grizzly bears and black bears (Schirokauer and Boyd 1998). Aversive conditioning was used to alter the behaviour of food conditioned bears. Whenever the bear was observed approaching within $30 \mathrm{~m}$ of a camp or developed area, it was aversively conditioned with plastic slugs, or cracker shells fired from a 12-guage shotgun 
used in combination with noise, throwing rocks, or spraying capsicum at the bears (Schirokauer and Boyd 1998). Eight of eleven bears avoided test camps and did not cause further problems during the season the aversive conditioning occurred (Schirokauer and Boyd 1998). Seven of the bears were subjected to aversive conditioning in the backcountry, four out of the seven bears avoided camps for at least two years (Schirokauer and Boyd 1998). However, the bears were only scared away during the season in which the aversive conditioning occurred. The higher success for backcountry aversive conditioning may be directly related to the temporary campsites, low number of people, and the education provided for backpackers on reducing human-bear encounters before entering the backcountry (Schirokauer and Boyd 1998).

Electric shock through radio collars is being used in the United States to administer nonlethal adverse stimuli to a predator when harassing livestock. Electronic collars and ear tags have been used to train cattle to avoid certain portions of pastures, such as riparian areas (Andelt et al. 1999). Currently, a study in Colorado is demonstrating the effectiveness of radio collars to disrupt predatory behaviour of bears (Shivik pers. comm.). The radio collar transmitter is hooked up to a pager through a computer. When a grizzly bear is present, the pager sends a message to warn the person that a bear is in the area. The person can use rubber bullets and crackers shells in combination with the radio collar that 'shocks' the bear when it is too close to the livestock. The radio collar becomes a form of a negative experience. The radio collars can be sound activated, providing an acoustical deterrent, and can also trigger scare devices to go off when the bear is present. Radio collars have proven to be an effective technique because the combination of a scare device and acoustical deterrent, which is only triggered when the predator is near, followed by a negative experience results in a high percentage of bears being scared away forever (Shivik pers. comm.).

The increasingly popular use of Karelian bear dogs has proven to be quite successful at conditioning bears to avoid human areas. Originally bred and trained in Finland and Russia for hunting brown bears, Karelian bear dogs have the instinct for handling bears safely (Quinlan 1999). Developed by Carrie Hunt through her Partners in Life Program by the Wind River Bear Institute, the use of Karelian dogs to protect people and property is a new concept in bear-human conflict resolution. The goal is to change both human and bear behaviours, avoid conflicts, and prevent bears from being conditioned to view human territories as potential food sources (Hunt 2000). Karelian bear dogs are used in combination with aversive conditioning tools and structured learning situations to teach bears to recognize and avoid human areas (Hunt 2000). When bears successfully locate food by venturing within human territory, rubber bullets, gunfire, and the dogs, reverse the positive association that bears acquire. An important result of the program's educational work has been the public's increased efforts to prevent bear conflicts. The public has responded by cleaning up bear attractants and by giving early and increased reports of bear problems because they understand that reporting will not lead to removal or destruction of the bears (Hunt 2000). Carrie Hunt has developed and applied bear shepherding techniques in 200-300 incidents each year. Many of these bears are alive today and none of the female grizzly bears worked with have been removed or destroyed (Hunt 2000). 
In Pincher Creek, Alberta, a study was conducted using Karelian bear dogs as an aversive conditioning agent (Quinlan 1999). The Wind River Bear Institute director Carrie Hunt worked with staff from Alberta Fish and Wildlife (Blairmore, Pincher Creek, Claresholm, and Cardston Districts) for two weeks to conduct 10 days of field trials with four Karelian bear dogs in July of 1999. Aversive conditioning using Karelian bear dogs was demonstrated in actual response work in the Pincher Creek area and in Waterton Lakes National Park. Since all scenarios allowed bear conflict situations to be resolved without removing the bears from their home range, the study showed that Karelian bear dogs are an effective tool for use in bear management activities in southwestern Alberta (Quinlan 1999). The field trials also showed many other applications for the bear dogs in bear management and response work.

Other breeds of dogs, such as the Great Pyrenees, the Anatolian Shepard, and the Akbash, have been used throughout history to protect livestock from predators (Ciarniello 1997). These guard dogs bond with livestock better than Karelian bear dogs, as they exhibit a stronger, more protective instinct. The dogs protect by scent marking the pasture, barking, and chasing predators. In order to be effective, the guard dogs must be bred and trained to protect livestock from predators. Unlike the Karelian bear dog, there are no programs in North America that breed these dogs or work with the pups (Ciarniello 1997). If a proper breeder and handler was involved in rearing and training these pups, the use of these dogs might prove more effective (Ciarniello 1997).

Emetic or foul tasting chemicals, such as lithium chloride $(\mathrm{LiCl})$, are used as aversive conditioning agents through conditioned taste aversion. Conditioned taste aversion occurs when ingestion of a food produces gastrointestinal illness, resulting in avoidance of that food (Ternent and Garshelis 1999). Taste aversion has been used in various studies involving coyotes, wolves, and bears to deter predators from feeding on livestock, beeyards, and human foods.

For bee predation, the most effective non-lethal tool is the electric fence. However, if the bear goes through the electric fence, conditioned taste aversion can help eliminate the problem. A study was conducted in the Peace River area of Alberta on the use of lithium chloride $(\mathrm{LiCl})$ and electrical fences as aversive conditioning agents to prevent black bears from damaging beeyards (Gilbert and Roy 1977). The study consisted of four scenarios: unfenced unbaited sites, unfenced baited sites, fenced unbaited sites, and fenced baited sites. The results of the study indicated that the combination of an electrical fence and $\mathrm{LiCl}$ was the most effective technique in preventing bears from damaging beeyards (Gilbert and Roy 1977). However, a follow-up study was conducted to evaluate the aversive conditioning techniques described by Gilbert and Roy (1977). Interestingly, the follow-up study concluded that $\mathrm{LiCl}$ was ineffective in reducing bear damage in beeyards (Dorrance and Roy 1978). The data suggested that the bears learned to avoid the bait, but not the beehives (Dorrance and Roy 1978).

Conditioning by taste aversion was studied in the Camp Ripley Military Reservation in Minnesota. Black bears regularly sought out, obtained, and consumed pre-packaged military foods, known as meals-ready-to-eat (MREs), making the bears a nuisance to 
personnel and a hindrance to military operations (Ternent and Garshelis 1999). Two adult females and three yearling offspring of one of these females were responsible for most nuisance activity in the reserve. Taste aversion experiments were conducted to reduce their attraction to MREs by using baited MREs with thiabendazole, an illnessinducing agent. The bears consumed the baits during the 122-day trial. In the end the bears rejected MREs even if they were not the same type of meal that was used in the treatment, but they continued to consume non-MRE foods that were not removed from the area. This aversion persisted in two bears one year later, but not in two years (Ternent and Garshelis 1999). Taste aversion conditioning may be an effective component of a management strategy to diminish nuisance activity, if availability of alternate human-related foods also is reduced (Ternent and Garshelis 1999).

In Joshua Tree National Monument in California, a study was conducted in campgrounds. Several coyotes (from 3 in August to 12 coyotes in November) were begging for food from visitors in the campground. Apparently the coyotes did not fear humans and were a potential hazard to visitors' safety. Attempting to discourage begging and scavenging by coyotes at the campground, a variety of baits treated with $\mathrm{LiCl}$ were used (Cornely 1979). The goal was to reduce the concentration of coyotes at the campground and force them to revert to hunting natural prey (Cornely 1979). After different types of baits were treated with $\mathrm{LiCl}$, the baits were placed around the campground and continuously observed. During the treatment, each visitor was contacted and asked not to feed the coyotes. Bait was taken 31 times, and within a month coyotes were refusing to take the baits (Cornely 1979). From January, when the treatments were terminated, until April, no begging problems or abnormal concentrations of coyotes were reported at the campground (Cornely 1979).

\subsection{Negative aspects of Aversive Conditioning}

Unfortunately aversive conditioning techniques and equipment are costly and time consuming. For aversive conditioning to be effective, it must be applied immediately upon occurrence of the undesirable behaviour and every time the behaviour is displayed. There cannot be a single food reward during the aversive conditioning period. In Alaska, a study used aversive conditioning, both physical and ingestional, to change bear food conditioned behaviour. Rubber bullets were used on 14 bears and an emetic (Thiobendazol) was added to garbage cans in Janeau. The results of the study showed that all but one bear continued to forage in town. The effectiveness of aversive conditioning agents was low as a result of the availability of other garbage in the area (McCarthy and Seavoy 1994). It is recommended to reduce garbage availability and other unnatural food attractions before administering aversive conditioning techniques.

One of the major limitations of aversive conditioning is that the technique could prove time and labour intensive (Gillin et al. 1994). However, if grizzly bear occurrences are only occurring within a short time frame then the time and effort required is less for effective results. In addition, managers should take into account the variables and circumstances that may limit the practicality of aversive conditioning techniques, such as safety factors, repeatability, bear sex and age characteristics, and extent of previous habituation (Gillin et al. 1994). Effectiveness and duration of adverse conditioning will 
depend on the personality of the bear, the degree of conditioning, attractiveness of the food source, availability of natural food sources, and the bear's previous experiences (MELP 1996).

\subsection{Summary of Recommendations}

The results of this study stress the need for effective long-term solutions to prevent and eliminate the sources of human-bear conflict in order to negate problem bear behaviour now and in future generations. To begin with, a management plan would include a bear awareness education program that would provide citizens with knowledge to reduce unnatural food attractants and information for co-existing with bears. Moreover, it would provide citizens with alternative strategies and resources that would reduce the availability of unnatural attractants, such as bear-resistant trash containers. Following that, aversive conditioning techniques would be used on nuisance bears to alter undesirable behaviour, to instil a fear of humans, and to avoid the removal or destruction of bears. In turn, a carcass pick-up service would immediately remove and properly dispose of domestic and wild animal carcasses from the core problem areas. Part of the management strategy would consist of the establishment of a local task force. The local task force's role would be to secure a co-operative effort with landowners by understanding their interactions with bears and in turn develop ways to help landowners and bears co-exist. In addition, landowners need to be provided with information on good livestock management practices. Lastly, the management strategies would involve research in order to understand grizzly behaviour and habitat use while further examining human-bear relationships and ways to reduce conflict. Application of the above strategies would reduce human-bear conflicts, reduce the numbers of bears relocated or destroyed, and reduce human impact on the health and population dynamics of grizzly bears. 


\subsection{LITERATURE CITED}

Alberta Environment. 2000. "Bears in Alberta: Their characteristics, history, behavior and management." Fish and Wildlife, Alberta Environment, and Alberta Government. URL: http://www.gov.ab/env/fw/bears/body.html [Accessed: 30 January 2001].

Alberta Environment. 2000. "Welcome to the Northwest Boreal Region!" Alberta Environment and Alberta Government. URL:

http://www.gov.ab.ca/env/regions/nwb/index.html [Revision date: 20 November 2000].

Alberta Environment. 1997. "Bears in Alberta: Their Characteristics, History, Behaviour, and Management." Alberta Environment Protection. Natural Resources Service. Edmonton, Alberta.

Alberta Forestry, Lands and Wildlife (AFLW). 1990. "Management plan for grizzly bears in Alberta." Wildlife Management Planning Series n.2. AFLW. Edmonton, Alberta.

Andelt et al. 1999. "Coyote predation on domestic sheep deterred with electronic dogtraining collar." Wildlife Society Bulletin, 27(1): 12-18.

Cat Specialist Group (CSG). 1996. "Management of Big Cats Near People." The World Conservation Union. URL: http://lynx.uio.no/catfolk/mjissues/mjchp 2d.htm [Accessed: 8 December 2000].

Ciarniello, Lana M. 1997. "Reducing Human-Bear Conflicts: Solutions Through Better Management of Non-Natural Foods." Ministry of Environment, Lands and Parks (MELP). Westworth, Brusnyk \& Associates Ltd. Valemount, British Columbia. Edmonton, Alberta.

Cornely, John E. 1979. "Aversive Conditioning of campground coyotes in Joshua Tree National Monument.” Wildlife Society Bulletin; 7(2): 130-131. Proc. Second Conference Sci. Res. National Parks.

COSEWIC. 2000. "Canadian Species At Risk." Committee on the Status of Endangered Wildlife in Canada. URL: http://www.cosewic.gc.ca/COSEWIC [Revision Date: 6 December 2000].

Dorrance, M.J. and L.D. Roy. 1978. "Aversive conditioning tests of black bears in beeyards failed." Vertebrate and Pest Conference, Sacramento, California. 8: 251-254.

Flath, R. and Gunson, J.R. 1995. "Discussion Paper on the Handling of Bears in Alberta." Occasional Paper n.15. Wildlife Management Division. Alberta Environmental Protection. Natural Resources Service. Edmonton, Alberta. 
Fritts, Seven H. 1998. "Wolf Depredation on Livestock in Minnesota." U.S. Fish and Wildlife Service. Patuxent Wildlife Research Center. Maryland, USA. URL: http://www.npwrc.gov/resource/1998/minnwolf/minnwolf.htm [Accessed: 13 November 2000].

Gilbert, B.K. and L.D. Roy. 1977. "Prevention of black bear damage to beeyards using aversive conditioning." Pp. 93-102 in Proceedings of the 1975 Predator Symposium (Phillips, R.L. and C.Jonkel, eds). Montana Forest and Conservation Experiment Station, Univ. of Montana, Missoula, MT.

Gillian, C.M., F.M. Hammond, and C.M. Peterson. 1994. "Evaluation of an aversive conditioning technique used on female grizzly bears in the Yellowstone ecosystem." Pp. 503-512 in Proceedings and papers of the Ninth International Conference on Bear Research and Management. Bears - Their Biology and Management (Claar, J.J. and P. Schullery, eds). Missoula, MT.

Hunt, Carrie L. 2000. "Wind River Karelian Bear Dogs: Partners in Life." Unpublished letter sent to people interested in the Partners in Life Program. Utah, USA.

Hunt, Carrie L. 2000. "Bear Shepherding to Reduce Human-Bear Conflict - The Partners in Life Program." International Bear News; 9(2): 14-19. Newsletter of the International Association for Bear Research and Management (IBA) and the IUCN/SSC Bear Specialist Group.

Hunt, Carrie L. 1984. "Behavioral Responses of Bears to test of Repellents, Deterrents, and Aversive Conditioning." M.S. thesis, Univ. Mont.

McCarthy, T.M. and R.J. Seavoy. 1994. "Reducing nonsport losses attributable to food conditioning: Human and bear behavior modification in an urban environment." Pp. 75-84 in Proceedings and papers of the Ninth International Conference on Bear Research and Management. Bears - Their Biology and Management (Claar, J.J. and P. Schullery, eds). Missoula, MT.

Ministry of Environment, Lands and Parks (MELP). 1996. "Human-bear conflict in British Columbia: draft discussion paper." Ministry of Environment, Lands and Parks, British Columbia.

Ministry of Environment, Lands and Parks (MELP). 1995. "Conservation of grizzly bears in British Columbia Background Report.” MELP. Victoria, B.C.

O’Brien, Anita. 1997. "Management Practices can Influence Predation.” OMAFRA Sheep and Goat Specialist. Government of Ontario. Ontario. URL: http://www.gov.on.ca/OMAFRA/english/livestock/sheep/facts/info_mgmtpredi nf.htm [Accessed: 8 December 2000]. 
Quinlan, R. 1999. “A Karelian bear dog program for Alberta." Natural Resources Service, Alberta Enviroment. Pincher Creek Area, Alberta.

Schirokauer, D.W. and H.M. Boyd. 1998. "Bear-human conflict management in Denali National Park and Preserve, 1982-94." Pp. 395-403 in Proceedings and papers of the Tenth International Conference on Bear Research and Management. Bears - Their Biology and Management (Miller, S.D. and H.V. Reynolds, eds). Fairbanks, Alaska and Mora, Sweden.

Schowalter, T. et al. 2000. "Status of Alberta Wildlife 2000: Preliminary status evaluation of the mammals." Fisheries and Wildlife Management Division, Natural Resources Service, Alberta Environment.

Ternet, M.A. and D.L. Garshelis. 1999. "Taste-aversion conditioning to reduce nuisance activity by black bears in a Minnesota military reservation." Wildlife Society Bulletin, 27(3): 720-728.

U.S. Fish and Wildlife Service. 2000. "U.S. Fish and Wildlife Service Endangered Species List." URL: http://ecos.fws.gov/species_profile.html [Revision Date: 21 December 2000].

Wade, D.A. and J.E. Bowns. 2000. "Procedures for evaluating predation on livestock and wildlife." URL: http://texnat.tamu.edu/ranchref/predator/pred.htm [Revision Date: 5 April 2000].

\section{Persons Contacted:}

Daloise, Richard. Regional Enforcement Manager, Nelson. Ministry of Environment, Lands and Parks. Conservation Office Service. Nelson, B.C. (250) 354-6394.

Silver, Rod. Habitat Conservation Trust Fund. Victoria, B.C. (250) 387-9853.

Hammond, Blair. Regional Manager, Southern Interior. British Columbia Conservation Foundation. Kamloops, B.C. (250) 828-2551 (ext. 301).

Van Spengen, Gary. Conservation Officer, Omineca-Peace Region. I/C Industrial Investigations. Ministry of Environment, Lands and Parks. Prince George, B.C. (250) 565-6416.

Hewitt, David. Wildlife Biologist. Caesar Kleberg Wildlife Research Institute. Texas A\&M University, Kingsville. Texas, USA. (361) 593-3963.

John A. Shivik. Research Wildlife Biologist. National Wildlife Research Center (NWRC). Colorado, USA. (970) 266-6088. 
Bruns, Eldon. Wildlife Biologist. Natural Resources Service, Alberta Environment. Rocky Mountain House district, Alberta. (780) 845-8235.

Olchowy, Kirk. District Conservation Officer. Natural Resources Service, Alberta Environment. Blairmore district, Alberta. (403) 562-3291.

Mamo, Charles. Wildlife Biologist. Central Rockies Wolf Project and Eastern Slopes Grizzly Bear Project, Southern Alberta. (403) 637-2655. 


\section{APPENDIX A}

Definitions for all of the complaint types, causes, and actions listed in Tables 1 to 4 .

Complaint Types:

\begin{tabular}{|c|c|}
\hline ivestoc & The grizzly bear killed a domestic animal. \\
\hline Aggressive Encounter & A grizzly bear displayed aggressive behaviour when encountering a human. \\
\hline Bear Destroyed & A grizzly bear was shot and killed by a person. \\
\hline Public Safety & $\begin{array}{l}\text { The grizzly bear, in a residential area or another area used by humans, became a public } \\
\text { concern. }\end{array}$ \\
\hline Property Damage & $\begin{array}{l}\text { The grizzly bear destroyed or damaged a complainant's personal items. } \\
\text { Such as fences, chicken pens, vehicles, and hay bales. }\end{array}$ \\
\hline Wildlife Predation & Grizzly bear killed and fed upon a wild animal. \\
\hline Wildlife Carcass & A person shot and killed a wild animal, leaving the carcass accessible to the bear. \\
\hline Relocation Required & $\begin{array}{l}\text { Conservation Officers translocated a bear from the area because the bear was becoming } \\
\text { a high risk to the public. }\end{array}$ \\
\hline Field Crop Dar & The grizzly bear was feeding in oat fields, which was causing damage to the crops. \\
\hline ee Predation & The grizzly bear damaged or destroyed beehives. \\
\hline
\end{tabular}

Causes:

\begin{tabular}{|c|c|}
\hline Domestic Carcass & The grizzly bear was feeding on a domestic carcass. \\
\hline Wildlife Carcass & The grizzly bear was feeding on a wild animal carcass. \\
\hline Livestock Predation & The grizzly bear killed a domestic animal. \\
\hline Garbage & $\begin{array}{l}\text { The grizzly bear was feeding on garbage in residential areas or human used areas } \\
\text { Garbage consists of human food, bird feed, animal feed, and other types of garbage. }\end{array}$ \\
\hline Field Grain & The grizzly bear was consuming oats in an oat field. \\
\hline Vegetation & The bear was consuming natural plants and berries. \\
\hline Curiosity & $\begin{array}{l}\text { A bear approached a human or an area with human activity, displaying no } \\
\text { aggressive or defensive behaviour. }\end{array}$ \\
\hline Unknown & It is unknown as to why the grizzly bear was in the area. \\
\hline Bee Predation & The grizzly bear was damaging or destroying beehives. \\
\hline Cub Protection & $\begin{array}{l}\text { A female grizzly bear displayed aggressive behaviour towards a human because } \\
\text { she was protecting her cubs. The sow was shot and killed by the complainant. }\end{array}$ \\
\hline Starvation/Injury & $\begin{array}{l}\text { The grizzly bear was suffering from starvation and injury. The bear was displaying } \\
\text { aggressive behaviour towards humans and becoming a high public risk. }\end{array}$ \\
\hline Illegal Hunting & $\begin{array}{l}\text { The bear was shot and killed by a complainant who was illegally hunting for grizzly } \\
\text { bears. }\end{array}$ \\
\hline Legal Hunting & $\begin{array}{l}\text { The bear was shot and killed by a complainant who was legally hunting for grizzly } \\
\text { bears. }\end{array}$ \\
\hline Wildlife Predation & The bear was hunting in the area for natural prey, such as elk, moose, and deer. \\
\hline
\end{tabular}


Actions:

\begin{tabular}{|c|c|}
\hline Monitored & NRS and the complainant left the bear alone and montiored the bear. \\
\hline Snare Set/No Capture & $\begin{array}{l}\text { NRS set up snares to capture the bear, but the bear was not captured. Assumption } \\
\text { was made that the bear had left the area and snares were removed. }\end{array}$ \\
\hline Cause Removed & $\begin{array}{l}\text { The cause that was attracting the bear was removed by Conservation Officers or by the } \\
\text { the complainant. Causes removed consisted of garbage, domestic and wild animal } \\
\text { carcasses. }\end{array}$ \\
\hline Bear Removed & $\begin{array}{l}\text { The grizzly bear was caught by a snare and was translocated to another area because } \\
\text { the bear was becoming a problem within the area. }\end{array}$ \\
\hline Bear Destroyed & $\begin{array}{l}\text { The bear was shot and killed by a Conservation Officer or by a complainant. } \\
\text { Conservation Officers killed the bear because the bear was injured or was a high } \\
\text { public risk. The complainant killed the bear because of an aggressive encounter, } \\
\text { illegal or legal hunting, livestock predation, or in self-defense. }\end{array}$ \\
\hline Refer to Other District & $\begin{array}{l}\text { The grizzly bear complaint was referred to another district by a Conservation Officer } \\
\text { because the complaint occurred outside of their district. }\end{array}$ \\
\hline
\end{tabular}




\section{APPENDIX B}

Survey questions given to the Conservation Officers to determine the extent of bear education in the Grande Prairie pilot area.

1) What types of complainants do you educate the most?

2) Have you done any education programs for children? If so, was it delivered in a classroom? For what ages? If in the future there was an education program for schools, which grade(s) do you think the program would have the greatest impact on?

3) Approximately how many educational talks have you done regarding bear aware education this year? Has the number increased from previous years? Can the assumption be made that all grizzly bear complainants have had some extent of education from Conservation Officers?

4) Do you see a greater demand for an educational program from the general public presently or in the future? Has there been an increase in requests from various groups who would like to see a program developed? If there is, what types of groups are requesting for an education program?

5) What are the main ideas you present when educating people? Is there any structure or planning made in your educational talks? Does the structure change depending on the complainant and the problem at hand?

6) If there was the development of an education program, what would you like to see in the program? Would you want the audience and deliverance of the program expanded?

7) If a program was developed, how do you thinks we can make the program successful, long-term, and reach lots of people in a short time?

8) Any other comments? 


\section{List of Titles in This Series}

(as of July 2001)

No. 1 Alberta species at risk program and projects 2000-2001, by Alberta Sustainable Resource Development, Fish and Wildlife Division. (2001)

No. 2 Survey of the peregrine falcon (Falco peregrinus anatum) in Alberta, by R. Corrigan. (2001)

No. 3 Distribution and relative abundance of the shortjaw cisco (Coregonus zenithicus) in Alberta, by M. Steinhilber and L. Rhude. (2001)

No. 4 Survey of the bats of central and northwestern Alberta, by M.J. Vonhof and D. Hobson. (2001)

No. 52000 survey of the Trumpeter Swan (Cygnus buccinator) in Alberta, by M.L. James and A. James. (2001)

No. 6 2000/2001 Brassy Minnow inventory at Musreau Lake and outlet, by T. Ripley. (2001)

No. 7 Colonial nesting waterbird survey in the Northwest Boreal Region - 2000, by M. Hanneman and M. Heckbert. (2001)

No. 8 Burrowing owl trend block survey and monitoring - Brooks and Hanna areas, by D. Scobie and R. Russell. (2000)

No. 9 Survey of the Lake Sturgeon (Acipenser fulvescens) fishery on the South Saskatchewan River, Alberta (June-September, 2000), by L.A. Winkel. (2000)

No. 10 An evaluation of grizzly bear-human conflict in the Northwest Boreal Region of Alberta (19912000) and potential mitigation, by Teresa Augustyn. (2001)

No. 11 Harlequin duck monitoring in the Northern East Slopes of Alberta: 1998-2000 preliminary results, by Jeff Kneteman and Anne Hubbs. (2000)

No. 12 Distribution of selected small mammals in Alberta, by L. Engley and M. Norton. (2001)

No. 13 Northern leopard frog reintroduction. Raven River - Year 2 (2000), by Kris Kendell. (2001)

No. 14 Cumulative effects of watershed disturbances on fish communities in the Kakwa and Simonette watersheds. The Northern Watershed Project. Study 3 Progress report, by T. Thera and A. Wildeman. (2001)

No. 15 Harlequin duck research in Kananaskis Country in 2000, by C.M. Smith. (2001)

No. 16 Proposed monitoring plan for harlequin ducks in the Bow Region of Alberta, by C.M. Smith. (2001)

No. 17 Distribution and relative abundance of small mammals of the western plains of Alberta as determined from great horned owl pellets, by D. Schowalter. (2001)

No. 18 Western blue flag (Iris missouriensis) in Alberta: a census of naturally occurring populations for 2000 , by R. Ernst. (2000)

No. 19 Assessing chick survival of sage grouse in Canada, by Cameron L. Aldridge. (2000)

No. 20 Harlequin duck surveys of the Oldman River Basin in 2000, by Dale Paton. (2000) 
No. 21 Proposed protocols for inventories of rare plants of the Grassland Natural Region, by Cliff Wallis. (2001)

No. 22 Utilization of airphoto interpretation to locate prairie rattlesnake (Crotalus viridis viridis) hibernacula in the South Saskatchewan River valley, by Joel Nicholson and Selwyn Rose. (2001) 
